\title{
Sartre, Schelling, and onto-theology
}

\author{
Sebastian Gardner
}

\author{
University College London
}

\begin{abstract}
It is well known that Sartre describes his form of existentialism as atheistic, and much of the rhetoric of Sartrean existentialism draws off the image of God's absence from the world. There are nevertheless, I argue, deep grounds for thinking that the coherence and well-groundedness of Sartre's thought requires that his phenomenological ontology take finally the form of an onto-theology: Sartre's ontology runs into difficulties concerning the origin of the For-itself and the unity of being; an onto-theology like Schelling's, which avoids the 'ontological optimism' that Sartre objects to in Hegel, both releases Sartre's ontology from its difficulties and furthers Sartre's central philosophical purposes.
\end{abstract}

On the view most often taken of his place in the history of philosophy, Sartre is located in the phenomenological tradition and regarded as inheriting a philosophical programme from Husserl which he then overhauls in the light of Heidegger's analytic of Dasein, in such a way as to give phenomenology an existential orientation which is missing from Husserl, and to inject into it a strong doctrine of human freedom which is not to be found in Heidegger: in sum, Sartre is a libertarian phenomenologist. On this view his philosophy has two levels. First, there is the relatively superficial, phenomenological and anthropological level at which Sartre offers intuitively resonant descriptions of scenarios and experiences drawn from everyday life. The purpose of these is often moralistic, and Sartre's interest in displaying human weakness and the convolutions of human motivation makes his philosophical work seem straightforwardly continuous with his literary output. At this level, Sartre appears as close in spirit to La Rochefoucauld and Proust as to any of the great modern philosophers.

Second, there is the level that comprises all of the themes in Sartre which map onto what are for us readily recognisable areas and topics of philosophy, analytic and phenomenological. Included here are Sartre's discussions of emotion, imagination, intentionality, the self and self-knowledge, reasons and causes, and other issues in the philosophy of mind and action, as well as issues in moral philosophy concerning the subjectivity of values, the scope of responsibility, and so forth.

The level in Sartre's philosophy that receives least attention - in English-language commentary at any rate - is his ontology, his theory of being-in-itself, being-for-itself and nothingness. ${ }^{1}$ While it is, of course, impossible to so much as state Sartre's central ideas without employing his ontological terminology, this does not compel one to take it seriously, and Sartre's ontological talk can be given a light interpretation. Sartre's categories of being can be understood 
simply as a way of expressing his widening of the orbit of phenomenological investigation, his rejection of Husserl's view that the reduction leaves us with a sphere of transcendental subjectivity and his contrary view that suspension of the natural attitude leave being included in the realm to be studied. In analytic commentary, the tendency to downplay Sartre's theory of being is pronounced, and the ontological vocabulary is treated, as often as not, as a mere system of notation, a kind of shorthand for making points about concepts and objects that do not engage fundamental, general ontological questions. So one contemporary commentator describes Sartre as expounding his theory of consciousness by means of a 'baffling barrage of metaphors', ${ }^{2}$ and in Gregory McCulloch's book on Sartre the whole business of Sartre's ontology is dealt with in two pages, in terms of the question whether or not Sartre is a substance dualist. ${ }^{3}$ Similarly, Phyllis Morris's study of Sartre's conception of personhood, subtitled 'An analytic approach', reconstructs Sartre in the light of Strawsonian descriptive metaphysics, which entails disregarding ontological questions except in so far as they are internal to our conceptual scheme. ${ }^{4}$

The picture of Sartre as a libertarian phenomenologist may seem to sit comfortably with Sartre's description of his own (and Heidegger's) form of existentialism - in contrast with the Christian form that it assumes in Gabriel Marcel and Karl Jaspers - as 'atheistic':

Atheistic existentialism, of which I am a representative, declares with greater consistency that if God does not exist there is at least one being whose existence comes before its essence [...] That being is man or, as Heidegger has it, the human reality [...] Since man is thus self-surpassing, and can grasp objects only in relation to his self-surpassing, he is himself the heart and centre of his transcendence. There is no other universe except the human universe, the universe of human subjectivity. This relation of transcendence as constitutive of man [...] it is this that we call existential humanism. This is humanism, because we remind man that there is no legislator but himself [...] Existentialism is not atheist in the sense that it would exhaust itself in demonstrations of the non-existence of God. It declares, rather, that even if God existed that would make no difference from its point of view. Not that we believe God does exist, but we think the real problem is not that of His existence; what man needs is to find himself again and to understand that nothing can save him from himself, not even a valid proof of God's existence. ${ }^{5}$

Elsewhere Sartre describes himself as 'refusing existence to God', in contrast with the positivists who 'refused to take a stand as to the existence of God'. ${ }^{6}$ This repudiation of God, or of a God's-eye point of view on man, may be thought to cohere with the indifference to fundamental ontological questions evinced in anglophone Sartre commentary. 
I will argue that this interpretation of Sartre is mistaken and will attempt to show what happens when the focus in Sartre interpretation is shifted towards the ontological framework. ${ }^{7}$ Some preliminary reasons for thinking it appropriate to give weight to Sartre's concern with ontology are the following. First, to state the obvious, if the ontological investigation were truly incidental to what is important in Sartre's philosophy, then it would be hard to understand why Sartre should have bothered with it. Had Sartre's intention been confined to issues in the philosophy of psychology and moral psychology, he could have proceeded on the Kantian, Copernican basis that the very task of philosophy can be nothing other than an elucidation of the human point of view, from and for the human point of view. I will argue that although Sartre is tempted intermittently to enclose his philosophical claims within such a Copernican rubric, he does not carry it through, and there are good reasons why he should not do so.

Second, taken as a libertarian phenomenologist, Sartre's position is scarcely defensible. Sartre appears wide open to attack, for it is no more plausible to claim that a phenomenological reduction can show freedom to be unlimited than that the phenomena of natural consciousness provide immediate acquaintance with unlimited freedom; the more so when it is denied that the reduction takes us to a level of pure transcendental subjectivity. Consequently Merleau-Ponty has no difficulty, in his critique of Sartre's libertarianism, in showing that what the phenomena appear to reveal is on the contrary a kind of obscure mutual imbrication of freedom with necessity which often leaves questions of responsibility undecidable. ${ }^{8}$ Put differently, the libertarian phenomenologist construal makes Sartre appear confused, as if he were attempting to implant Kant's transcendental freedom into a Husserlian context (as if he thought that noumenally-grounded freedom could be 'found' in the appearances).

I shall argue that these two points are interconnected: it is because Sartre recognises that his claim for the reality of human freedom requires more than can be got from a Copernican phenomenology, that he develops his account of human reality within an ontological framework. Sartre's limitation, I will argue, is that his account of the framework is incomplete, and that what he actually requires for his purposes is something closer to Schelling's onto-theology. ${ }^{9}$ In this way, then, I will attempt to show that the ontological dimension of Sartre's philosophy puts pressure on Sartre's avowal of atheism. ${ }^{10}$

\section{Being in general and the origin of the For-itself}

Sartre's most general statements about ontology and the end-point of philosophical enquiry are contained in two relatively short but very dense sets of passages in Being and Nothingness, the first 
from the final section of the Introduction (sect. VI, 'Being-in-itself': BN xxxviii-xliii), the other from section one of the Conclusion (sect. I, 'In-itself and for-itself: metaphysical implications').

1. In the Introduction, having discriminated the mode of being of consciousness from that of its objects, Sartre writes:

[T]he preceding reflections have permitted us to distinguish two absolutely separated regions of being: the being of the pre-reflective cogito and the being of the phenomenon. But although the concept of being has this peculiarity of being divided into two regions without communication, we must nevertheless explain how these can be placed under the same heading. That will necessitate the investigation of these two types of being, and it is evident that we cannot truly grasp the meaning of either one until we can establish their true connection with the notion of being in general and the relations which unite them. (BN xxxix)

In advance of and in preparation for giving an account of 'being in general', Sartre then gives what he calls his preliminary account of the region of being which properly deserves the name, that is, what he calls being-in-itself. Being-in-itself, or more simply 'being', is beyond necessity and possibility, beyond affirmation and negation, beyond activity and passivity, beyond time and change. It 'is itself' in a sense so strong as to exclude selfhood - 'being is at bottom beyond the self' (BN xli).

Being also cannot be conceived as created, first because creation would require of being that it be passive, and second because no coherent account can be given of the relation of being to God, conceived, as Sartre has it, as (divine) subjectivity. If being had been created, Sartre says, still it 'would be inexplicable in terms of creation, for it assumes being beyond the creation' ( $\mathrm{BN} \mathrm{xl})$; anything that could be explained in terms of divine subjectivity would 'disappear' and 'dissolve' into it, and would not stand outside it in the sense required for being.

Being is therefore, for Sartre, beyond reason and explanation. However, Sartre insists that this (Parmenidean or quasi-Spinozistic) characterisation of being is not to be understood perspectivally, in Kantian fashion. The reason why being is beyond explanation is not that our cognitive capacities are thus and not otherwise: it 'has nothing to do with our position in relation to it; it is not that we are obliged to apprehend it and to observe it because we are "without" [...] The in-itself has nothing secret' (BN xlii). ${ }^{11}$ So we are not to confuse Sartre's being-in-itself with Kant's thing in itself, even though they share a range of negative determinations. In comprehending beingin-itself as beyond explanation, we cognise it as it is in itself.

At this point, as Sartre acknowledges: 
A multitude of questions remain unanswered: What is the ultimate meaning of these two types of being? For what reasons do they both belong to being in general? What is the meaning of being in so far as it includes within itself these two radically separated regions of being? If idealism and realism both fail to explain the relations which in fact unite these regions which should be by all rights without communication, what other solution can be found? (BN xliii)

Why is it necessary to conceive the relation between the two types of being? The answer given here is that we do 'in fact' find them to be related, in all our consciousness of objects: so we must explain the possibility of communication between the two realms, and the account so far gives us only 'two closed totalities without possible communication' (BN xl).

2. I turn now to consider the answer to these questions given by Sartre in the Conclusion of Being and Nothingness.

By the time we have reached the Conclusion, the opening contrast of consciousness and object has been worked up into the opposition of For-itself and In-itself, so the dualism is reformulated as that of 'being which has to be what it is', being-for-itself, and 'being which is what it is' (BN 617). But the question remains unchanged, namely whether or not 'Being (as a general category belonging to all existents)' is divided by a hiatus into 'two incommunicable regions' (BN 617).

Sartre says that our research in the course of the book enables us to answer the question of how the two regions can be related to one another: 'the For-Itself and the In-itself are reunited by a synthetic connection which is nothing other than the For-itself itself' (BN 617). This relation has the following character: it is 'a tiny nihilation which has its origin at the heart of Being', and 'this nihilation is sufficient to cause a total upheaval to happen to the In-itself. This upheaval is the world' (BN 617-618); 'As a nihilation it is made-to-be by the in-itself' (BN 618); 'the appearance of the for-itself is the absolute event which comes to being' (BN 619). Sartre gave a hint of this in the Introduction, when he wrote: 'Everything happens as if, in order to free the affirmation of self from the heart of being, there is necessary a decompression of being' (BN xli).

The next question must be: Why, or how, does the For-itself come about from the In-itself? The original, Parmenidean account that Sartre gave of being-in-itself in the Introduction did not explain this possibility. Nor does Sartre pretend that the trace of nothingness in being can be passed off as a brute ontological fact. For example, he takes care to say in the quotation above (BN 617), that the For-itself is a nihilation which has its origin in Being, not that it is in Being; so the question 
is expressly left open concerning the ground in Being of the nihilation which the For-itself consists in. Sartre acknowledges that explanation is still needed:

[T]his immediately gives rise to a metaphysical interrogation [...] There is therefore room here for a metaphysical problem which could be formulated thus: Why does the for-itself arise in terms of being? [Pourquoi le pour-soi surgit-il à partir de l'être?] (BN 619)

Now this is a question that Sartre, after spending several pages discussing it (BN 619-625), does not answer. What his discussion consists of instead is a critique of some attempts to answer it, alongside an account of why in fact we should suppose that the question does not need to be answered. The key to Sartre's argument is a distinction that he formulates, implied in the quotation above, between ontology and metaphysics, his claim being that metaphysical questions are, if not empty, then at least philosophically secondary. I will return to this shortly, but first I want to juxtapose Sartre's idea of an original 'decompression' in being with some ideas in Schelling.

\section{Schelling's onto-theology}

The question which dominates Schelling's philosophy through its many stages of development is that of the derivation of the world from the absolute, and the general form of the solution that he favoured in the earlier phase of his thought (expressed most clearly in the identity philosophy writings of 1801-1802) is to envisage the absolute as transcending, by way of being 'indifferent' between, all of the categories that provide the oppositions which in turn give the world its structure and reality.

Even put in these very bald terms, it is clear that Schelling's enterprise has some bearing on Sartre, but there is one particular phase of Schelling's thinking, in which he becomes dissatisfied with the suggestion that indifference is itself enough, where in his formulation of the problem and its solution he comes especially close to Sartre. In the passage quoted below from his Weltalter, Schelling claims that there are two principles in time, by which he means here, the development of the world in time. One principle strives forward, driving toward development, and the other holds back, inhibiting [hemmend] and striving against development. If there were no inhibition, then there would be no time, because development would occur in an uninterrupted flash; yet if the inhibiting principle were not constantly overcome by the first, there would be absolute rest and standstill and hence no time. 
It is necessary to conceive of these principles in everything that is - indeed, in being [Seyn] itself. Every entity, everything that is, wants to be in itself and out of itself at the same time. It wants to be in itself inasmuch as it posits or collects itself together as what-is [als Seyendes], as a subject; to this extent it opposes development and expansion. It wants to be out of itself inasmuch as it desires to be what it is in itself once more, and hence externally. In the first case it is something withdrawn by itself, which sets itself in opposition to what is outside of it; but it sets itself in opposition only in order to reveal and declare itself against this outside as what it is in itself. It cannot, therefore, remain in this withdrawn condition.

Likewise with being. For considered purely as such, being is selfless and completely immersed in itself. But on precisely this account, being withdraws its opposite into itself and is a constant thirst for essence, a yearning to attract what-is, or to attract a subject, so that by means of this subject it might step forth from a state of mere potentiality into activity [...]

Thus, the principles we perceive in time are the authentic inner principles of all life, and contradiction is not only possible but in fact necessary. ${ }^{12}$

And a second passage, from later in the same work:

We understand eternity [= the 'First', the ground of God, time, and world] to mean the whole [...] eternity is not conscious of itself [...] Being is, for its part, perfectly indifferent [...] But the more this composure is profoundly deep and intrinsically full of bliss, the sooner must a quiet longing produce itself in eternity [...] This is a longing to come to itself, to find and savor itself; it is an urge to become conscious [...] This longing, however, does not become action or motion. The only perfect similarity would be with human nature in its first becoming and progress toward active existence. ${ }^{13}$

What Schelling sketches in these passages is therefore the idea of an original conflict of principles within being, which generates conscious subjectivity, and in so doing transposes itself into the relation of subject to world. ${ }^{14}$

Leaving aside all the details, the point I wish to draw attention to is simply the way in which Schelling's speculation offers itself as an immediate extension of the account given by Sartre of the upsurge of the For-itself, his idea of a 'decompression of being' that releases the selfhood of beingfor-itself. What Schelling's speculation adds to Sartre's account is the making-intelligible of the origin of the For-itself. It does so, furthermore, in a way that is consistent with Sartre's rejection of a relation of creation: the emphatically pre-intentional character of the process described by Schelling accords with Sartre's emphasis on the non-intentional character of the upsurge of the For-itself, 
which he refers to as an 'event' that 'happens to' being-in-itself, not as something done by being-initself.

What is required in order for Sartre's event of upsurge of the For-itself to be explained in Schelling's speculative terms, is that its ground, which Sartre conceives only as a nihilation which somehow has its origin in being-in-itself, be reconceptualised in Schelling's idealistic terms, as the absolute or eternity. What would then be said is that at the point where what Sartre calls being-initself gives rise to the upsurge of the For-itself, being-in-itself $i s$ what onto-theology calls the highest being. ${ }^{15}$ It is too soon to claim that Sartre is obliged to accept this identification, but it may already be noted in support that Sartre himself describes his original Parmenidean conceptualisation of being-in-itself as only 'preliminary'.

Schelling did not have the opportunity to criticise Sartre, but he did confront a position which is in the relevant respect like Sartre's, namely Fichte's. Fichte's theory of the absolute Ich, though it affirms the priority (which Sartre rejects) of I over not-I, concurs with Sartre in denying that there is any intelligible philosophical path of derivation running from the not-I, or In-itself, to the I or For-itself. Thus both Fichte and Sartre claim the autonomy, in this sense, of the I. ${ }^{16}$ And this is Schelling's chief point of criticism of Fichte: Schelling thinks that the Ich can be understood only as arising from being, and so that it is incoherent to ascribe to it the kind of priority that it has in Fichte. Whether or not Schelling is right about this, it helps us to see the logical relation between Schelling and Sartre: it is no accident that Schelling's reflections should proceed from the point where Sartre's enquiry stops, since Schelling developed his position partly in response to what he perceived as the limitations of a position, namely Fichte's, which in the relevant respect coincides with Sartre's.

The claim can be developed by looking at other places where Schelling tries to articulate the birth of the world and human subjectivity. In one key text, which marked his turn from identity philosophy to the outlook of the Weltalter, Schelling refers to the formation of the world out of the absolute as a 'fall', Abfall, in explicit parallel with the Christian (or Gnostic) notion, or Abbrechen. ${ }^{17}$ And this too resonates with Sartre, who encourages us to think of human being as a 'fallen', negated form of being-in-itself (he calls it a maladie, BN 621): as if it had once been a thing but had undergone a kind of metaphysical destruction in which all of its being had been stolen from it, so that it now inhabits the earth as a kind of ghost or shadow. Sartre repeatedly allows the thought to suggest itself that the annihilation of being that brings about the For-itself occurs for reasons which are in some sense moral or theological: in some sense things have 'gone wrong' ontologically, as if, in some reversal of the Prometheus myth, our 'loss' of being came by way of a punishment or act of theft visited upon us. In echoing traditional Christian theological and mythological notions, and thereby showing that he is well aware of the proto-theological character of the territory his 
philosophy deals with, Sartre has no intention of granting them legitimacy: his aim is on the contrary to replace outright such pre-modern figures of thought with a philosophical discourse appropriate to modern disenchanted secular subjectity, that is, phenomenological ontology. Schelling, by contrast, regards the notions of theology and mythology as objects to which philosophical reason should accommodate itself, and accordinly aims to develop a metaphysics that will allow us to see how theological and mythological forms of thought have not merely metaphorical validity but actual truth. In Sartre's terms, Schelling's speculation counts as 'metaphysics' rather than 'ontology', and is supposed to fall prey to the objections that, we will see, he puts to metaphysics as a philosophical enterprise. The next question is therefore whether Sartre does have grounds for devaluing what he calls 'metaphysics'.

\section{Sartre on ontology and 'metaphysics'}

The difficulties in Sartre's discussion of ontology and metaphysics begin with his account of the distinction itself. Sartre writes:

We in fact apply the term 'metaphysical' to the study of individual processes which have given birth to this world as a concrete and particular totality. In this sense metaphysics is to ontology as history is to sociology. (BN 619)

As he puts it slightly later, ontology is concerned with 'structures of being', and metaphysics with 'events' (BN 620).

However, since obviously, and as Sartre himself says, metaphysics is not concerned with events (and relations of before and after) in a properly temporal sense, ${ }^{18}$ this comparison does not clarify the distinction: in order for it to work, we would need to know what structures and grounds count as non-temporal analogues of historical ones, while yet remaining distinct from the structures and grounds of ontology, and Sartre does not supply this information. Sartre also suggests that metaphysics concerns itself with 'why' questions, but again this does not make the distinction clear: the distinction of ontology from metaphysics cannot be drawn in terms of the distinction of description from explanation - as if ontology addressed the question 'what is there?', and metaphysics the question 'why are things as they are?' - since the ontology of Being and Nothingness is itself explanatory at all of its levels. The conclusion to draw, I think, is that ontology and metaphysics compose two distinct stages of a single enquiry, and not two different kinds of enquiry. ${ }^{19}$ This at least leaves it open that the stage of further enquiry that Sartre calls metaphysics has the inferior status that he claims for it. 
Sartre's official distinction of ontology and metaphysics is less important, in any case, than his attempt to show that a line should be drawn under the question of why the upsurge of the Foritself takes place. Sartre shows that there is only one candidate for an answer to this question, which is namely that being-in-itself gives rise to being-for-itself in order to 'found itself', to become selfgrounding, or as Sartre puts it, in order to become God, a self-cause. This is to picture the For-itself as the self-relation of the In-itself. ${ }^{20}$ This would indeed provide a full answer to the question of how the For-itself is related to the In-itself. But if the For-itself is a self-relation generated out of being, then being's generation of this self-relation must be a purposive project. What could the In-itself's purpose be? Sartre suggests an answer, namely the overcoming of its own contingency:

[E]very process of a foundation of the self is a rupture in the identity-of-being of the initself, a withdrawal by being in relation to itself and the appearance of presence to self or consciousness. It is only by making itself for-itself that being can aspire to be the cause of itself. (BN 620)

Thus: 'If the in-itself were to found itself, it could attempt to do so only by making itself consciousness' (BN 620). But Sartre refuses to affirm the antecedent. And with good reason, since to do so would be to attribute a project to the In-itself, that is, it would compel him to revise his conception of being-in-itself:

Ontology here comes up against a profound contradiction since it is through the for-itself that the possibility of a foundation comes to the world. In order to be a project of founding itself, the in-itself would of necessity have to be originally a presence to itself - i.e., it would have to be already consciousness. (BN 621)

Accordingly Sartre says that:

Ontology will therefore limit itself to declaring that everything takes place as if the in-itself in a project to found itself gave itself the modification of the for-itself. (BN 621).

At this point one might have expected Sartre to declare that metaphysical enquiry into the origin of the For-itself is impossible, since, on his own account, there is only one possible answer to the question, and that answer is a 'profound contradiction' of what he holds to be a solid, unrevisable result of ontological enquiry. What he in fact does is something else. He suggests instead that there 
is indeed a further task of metaphysical enquiry, while at the same time implying its limited worth if not futility:

It is up to metaphysics to form the hypotheses which will allow us to conceive of this process [the upsurge of the For-itself ... But it] is evident that these hypotheses will remain hypotheses since we can not expect either further validation or invalidation. What will make their validity is only the possibility which they will offer us of unifying the givens of ontology. (BN 621)

But this is strictly incorrect, since in the present instance there is only one hypothesis which metaphysics can form, and it requires Sartre to reinterpret what he held to be a 'given' of ontology. Sartre's inexactness here is a sign, I think, that a deep and unresolved tension has emerged between the onto-theological trajectory of his ontological enquiry, of which he is not unaware, and his interest in constructing an ontology which is theology-proof.

It is also a sign of the tension referred to earlier between Copernican and non-Copernican strains in Sartre's thought. ${ }^{21}$ On the one hand, Sartre is drawn to the strategy of Kant's first Critique, of setting aside as empty all questions that cannot be answered in terms of the contents and purposes of the human point of view; on the other, Sartre repudiates this approach, both as idealistic, and as failing to yield sufficiently strong philosophical groundings. ${ }^{22}$

This interpretation of Sartre as combining unresolved Copernican and non-Copernican elements is supported if we look at Sartre's reason for granting the legitimacy in the first place of the awkward question of the upsurge of the For-itself. Questions about 'the origin of being' or 'the origin of the world' are, he says, 'either devoid of meaning or receive a reply within the province of ontology' (BN 619), i.e. they have already been answered earlier in Being and Nothingness. This is because, since being itself is 'without reason, without cause', the question, 'Why is it that there is being?', can only mean, Why does being take the form of a phenomenon for us?, and this question, he says, is answered by saying that the For-itself is such that 'there is' being, since the For-itself makes being appear, as a phenomenon (BN 619). The question of the origin of the For-itself, on the other hand, is one that its own nature gives it a right to pose, according to Sartre: the whole nature of the For-itself is 'interrogative', i.e. reason-seeking, so it cannot be denied the right to ask for the reason for itself.

This asymmetry, however, seems unconvincing. If the For-itself is within its rights to ask for the reason for itself as such and in general (as opposed to the reason merely for its particular individualised being) then it can legitimately ask the same question of being as such: if the Foritself can step out of itself and take the semi-external, sideways-on view of itself which is necessary 
in order for it to pose the trans-Copernican question of the reason for itself, then why-questions $d o$ have application not merely within the perspective of the For-itself. ${ }^{23}$ If Sartre cannot consistently confine why-questions, reason-seeking, to the realm of the For-itself, in Copernican fashion, then his original argument for claiming that being-in-itself is 'beyond reason' is overturned: it must be concluded that categories of reason and explanation are applicable to being-in-itself.

It might at this point be proposed that we take a step back, with a view to cutting short the discussion. Since the idea that the For-itself originates in an ontological act of the In-itself proves so troublesome, it may be wondered how important it is for Sartre. What exactly would be lost by eliminating it from Sartre's picture? Could Sartre not have asserted instead that the existence of the For-itself in addition to the In-itself is a brute, ultimate matter, claiming on Copernican grounds that we must regard this fact as, so far as we are concerned, philosophically final? There is in fact a compelling reason why Sartre must hold on to the idea of an upsurge of the For-itself from the Initself. It is of the essence for Sartre's motivational hermeneutics that the human subject be conceived as (in) a condition of primordial lack, manque - this is what makes the project of becoming 'in-itself-for-itself' a necessity, rather than an unintelligible whim - and the claim that the For-itself comes about from the In-itself, burdened with the impossible purpose of founding itself, is crucial in rationalising this claim: without it, it would be hard to understand why the For-itself should be given to itself as a lack of being, as equipped with a need for being, rather than as simply not possessing being. ${ }^{24}$

\section{The totality of being}

Thus far I have argued that Sartre's appeal to a distinction of ontology and 'metaphysics' does not allow him to solve the problem of conceiving the origin of the For-itself, and that this appeal can be regarded as reflecting a vacillation between Copernicanism and non-Copernicanism, evidence for which can be found also in Sartre's handling of the question of why there is being. However, before the conclusion can be drawn that Sartre is indeed obliged to make the transition to onto-theology, it is necessary to consider what Sartre says in the rest of section 1 in the Conclusion where he returns to his original question concerning 'being in general', for in now asking about 'being in general' Sartre is really taking up the question of the origin of the For-itself in a different form, as it were, synchronically rather than diachronically. ${ }^{25}$

Our situation with regard to the concept of being in general, Sartre says, is the following. In order to give sense to that concept, there must be a concept of the totality of being, and the concept of totality is that of a whole whose parts cannot exist independently of one another or of the whole, i.e. whose parts are all internally related. ${ }^{26}$ Thus, Sartre continues, to conceive being as a totality is 
equivalent to conceiving it as a 'self-cause', an 'ens causa sui' (BN 622). And this conception is unacceptable to Sartre, for two reasons. First, if being is conceived as a totality which includes Foritself and In-itself, then the In-itself is ontologically dependent on the For-itself: 'the in-itself would receive its existence from the nihilation which caused there to be consciousness of it' (BN 622). The totality of being would be an 'ideal being', he says, with 'the in-itself founded by the for-itself and identical with the for-itself which founds it' (BN 623). And this of course contradicts Sartre's claim that while consciousness is bound to the In-itself, ${ }^{27}$ the In-itself is in no way dependent on the Foritself. Second, it is a tenet of Sartre's that the concept of self-cause is contradictory ('impossible', BN 622).

Again - as with the hypothesis that the For-itself originates in the In-itself - one would expect Sartre to call a halt at this point by declaring (as a consistently Copernican position would allow him to do) that the concept of the totality of being is null and void, and once again he does not do this, for the reason that, he says, we are already, in speculating on being as a totality, giving application to and hence presupposing the legitimacy of that concept: we have already raised a question from a standpoint which presupposes the concept of the totality of being (BN 622) and we know that it is necessary for us to occupy that standpoint. ${ }^{28}$ Since we cannot discard the concept of the totality of being, instead Sartre says that the totality of being must be conceived as what he calls a 'detotalised totality', and he offers various equivalent formulae and analogies in his attempt to explain this idea. A 'detotalised totality' is the form that results from the destruction of a totality, where the destruction extends not to the existence of its components but only to their inter-relation, the destruction, therefore, of a form rather than of its contents. Sartre calls it 'a decapitated notion in perpetual disintegration', a 'disintegrated ensemble' (BN 623), and so on.

The concept of 'detotalised totality' has been used on earlier occasions in Being and Nothingness, in application to the structure of the self and to the unity of self and other, but in those contexts it was employed only descriptively, and was not required to bear the weight of furnishing a solution to a philosophical problem, as it is here.

Again Sartre seems not to have arrived at a stable point. The idea of detotalised totality depends, as does his definition of metaphysics, on Sartre's use of a relation that is not temporal but rather the analogue of a temporal relation: being as we find it is 'detotalised' because it is being 'after' its loss of unity. Granting this concept of a para-temporal relation, the problem lies with the fact that the contradiction which dwells according to Sartre in the concept of self-cause is in no way avoided by the shift to talk of a detotalised totality: something can be conceived as a detotalised totality only if the original totality from which it is supposed to have proceeded in its para-temporal way is at least genuinely conceivable. It is true that Sartre does not suppose the 'lost' totality of being to have ever been actual - the concept is in some way regulative - but it is one thing to 
declare that a metaphysical concept has only regulative status, as Kant does with reason's transcendental ideas, and another to declare that our thought is regulated by a concept which contains a contradiction. Quite possibly a claim of this sort could stand in the context of some sort of metaphysical fictionalism like Hans Vaihinger's, but Sartre's ontology cannot be understood in a fictionalist manner. ${ }^{29}$

Sartre recognises this problem and he backs off from the paradoxical claim that being is thinkable only in terms of a contradictory concept by using, as before, the formula 'as if', comme çi, in formulating his claims: 'Everything happens as if the world, man, and man-in-the-world succeeded in realizing only a missing God. Everything happens as if the In-itself and the For-itself [...]' (BN 623; italics added). Sartre closes the discussion by invoking the ontology/metaphysics distinction, reminding us that the question of totality 'does not belong to the province of ontology' and suggesting that it is a matter of indifference whether we think of being as 'a well marked duality or as a disintegrated being' (BN 624). Again this somewhat misrepresents the situation, for Sartre has already told us that the dualist conception is untenable, which leaves the notion of detotalised totality as the only concept which we can employ.

Yet this concept is contradictory. As before, something has to give. Being has to be conceived as a totality, and this can be done, but only if Sartre gives up two things: first, his claim that being-in-itself is absolutely independent of the For-itself (this must be treated as a merely provisional result which is revised at the end of the day), and second, his claim that the concept of self-cause is contradictory (a claim for which Sartre gives, as far as I can see, no compelling argument)..$^{30}$

There is one more possibility that deserves consideration. It might be suggested that the problem of the totality of being should be understood in terms of a task which it falls to us to complete. On this proposal Sartre's claim should be that the attempt to think being as a totality and the judgement that being is a 'detotalised totality' consist, when properly understood, in setting oneself the task of totalising being, through some sort of progressive humanisation of the in-itself. ${ }^{31}$ Such a strategy, in which a theoretical demand for explanation is transformed or dissolved into a practical demand and a theoretical question receives its 'answer' in the agent's doing or undertaking, would be genuinely Fichtean: it would take as its model Fichte's transition from theoretical reason to practical reason in Part III of his 1794 Wissenschaftslehre. ${ }^{32}$ This approach, it might be claimed, resolves the difficulties of Sartre's ontology while allowing him to steer clear of onto-theology.

The claim that Being and Nothingness may be read as an account of how the world must appear and be conceived from the standpoint of free agency is certainly plausible; various considerations may be held to support a Fichtean reading of Sartre. ${ }^{33}$ The question of the precise degree to which Sartre may be supposed to be Fichtean is too complex to be explored here, but the 
key points for present purposes are the following. First, in order for Sartre to hope to dissolve a problem of theoretical philosophy by practical means, he would need to share not just Fichte's emphasis on freedom but also Fichte's metaphilosophical view of the radical primacy of the practical, ${ }^{34}$ but there is an absence of explicit textual support for this claim. Second, and in any case, the problem noted earlier with a 'regulative' interpretation of the concept of totality of being recurs on the practical interpretation. In order that an agent may take up a task - even one that is infinite, in the sense of requiring infinite time for its completion - it is necessary that its object be coherent: the task of drawing a square circle, for example, is not an infinite task but one that cannot be taken up. The $U r$-task in Fichte, of translating Not-I into I, makes sense because Fichte's account of the being of Not-I is idealistic. Sartre, however, not only denies that the concept of the totality of being can be known to be realised but affirms the conceptual barrier to thinking of being as a unified totality. This does make the task of 'totalising being' like that of drawing a square circle.

\section{Onto-theological grounding: freedom and ethics}

The discussion in the last two sections is intended to show that there are pressures within Sartre's thinking that can be resolved only through the conversion of Sartre's nominally atheistic metaphysics into a Schellingian onto-theology. It is true that, just as Sartre's enquiry comes to an end at a point where philosophical thought gives out, so too does Schelling's: Schelling's account of longing and striving and so on is, as he takes pains to stress, intended to take over where ordinary, 'rationalistic' philosophical explanation gives out. Both thinkers, therefore, end up having to concede that in a way reality defeats the task of philosophical explanation. Schelling's end-point, however, lies one large step further down the path of explanation than Sartre's and, most importantly, Sartre's end-point is problematic in a way that Schelling's is not: Sartre's enquiry terminates with 'as if ...' propositions in which what follows the 'as if' stands in contradiction with the philosophical explanation which has preceded it. Schelling's account, by contrast, does not snap back on itself in this way.

All the same, it may be asked whether, pressures of consistency aside, there is anything that can be held to motivate in a more positive sense the reinterpretation of Sartre's ontology in Schelling's terms. I think there are two respects in which this is the case.

1. One of the questions which it is most natural to ask about Sartre is what he means by freedom. Sartre claims that our freedom is unlimited, and he says a great deal about what freedom is not, rejecting familiar compatibilist, incompatibilist, Kantian-noumenal, and so on, conceptions of freedom, but where one would expect Sartre to tell us what it actually $i s$, we find him instead saying 
that freedom is 'indefinable and unnamable' (BN 438). ${ }^{35}$ The puzzle is why Sartre does not think that this simply collapses the concept.

Sartre's difficulty is confirmed when comparison is drawn with Kant and Fichte, who also face the task of defending their strong claims for the objective reality of freedom, but who have the moral law to appeal to: on their account, the fact of reason, of pure practical reason, gives an epistemological ground for attributing reality to the idea of freedom. Sartre, not having this account of the moral law, cannot borrow the Kantian-Fichtean epistemology of freedom.

Part of the answer is that it is the job of his phenomenological ontology as a whole to articulate Sartre's insight into freedom. This strategy of devolving to the system as a whole the explication of its central concept follows the German idealist pattern, and it is not hard to see that Sartre's account of freedom has the same form as Schelling's account of the absolute: both are taken as the only possible starting point and goal of philosophy, and are held to be underivable and beyond the possibility of proof in any sense, and instead to be exhibited through a demonstration of the inadequacy of supposing otherwise, conjoined with an exposition of the complete system of philosophy. Sartre's view is perhaps that this is all that is required: he supposes that, once we have understood the For-itself's mode of being, then we have understood what freedom is ('freedom is identical with my existence', BN 444).

However, this leaves Sartre's position vulnerable in an important respect. Sartre remains open to the objection that his philosophical system, while fully coherent, may nevertheless be merely the expression of a vast illusion. Sartre does not worry about this possibility, presumably because he thinks that the traditional opposition of appearance and reality has been overcome in phenomenology. But even if he is right that phenomenology does away with the distinction with regard to the objects of consciousness, it does not follow that the distinction cannot still be mobilised with reference to the total realm of consciousness as such. Thus it remains entirely possible that all of Sartre's theory of nothingness, freedom, the mode of being of the For-itself, etc., is simply the expression of a systematic illusion: it is possible that our Sartrean belief in the reality of everything over and above being-in-itself - everything which his ontology of the For-itself comprehends - is empty, and that in reality there is nothing but being-in-itself. ${ }^{36}$

One might perhaps think this possibility dismissable, on the grounds that in order to explain away Sartre's For-itself in terms of an original illusion one must at least grant that there exists an illusion, and that illusions are, as Sartre would put it, signs of rupture with being-in-itself. But this would be to appeal, circularly, to the authority of our understanding of our phenomenology as philosophically significant in the way maintained by Sartre, which is just what stands in question. Moreover, what makes this eliminativist possibility one that Sartre is obliged to take seriously as more than a merely logical possibility, is the fact that on his own account freedom is ontologically 
secondary: its being is conditional upon that of being-in-itself. Freedom is not ontologically primary, for Sartre, and furthermore there is on his own account, as we have seen, a 'profound contradiction' in seeing how freedom can arise from that which is ontologically primary. And this is more than enough to motivate the thought that the whole edifice of so-called 'human reality' may be an illusion. ${ }^{37}$

If we now compare Sartre with Schelling, we see how Schelling's speculation, in which we start not from being-in-itself but from what Schelling variously calls the eternal, the absolute, the ground and so on - in which freedom is comprehended - is a more effective story from the standpoint of substantiating the claim of the reality of human freedom. Schelling's ontology makes freedom ontologically original, and this makes it impossible to raise the Spinozistic possibility as an internal objection to the claim for the reality of human freedom. In sum, Schelling shows how Sartrean freedom may be grounded without being compromised. ${ }^{38}$

2. An onto-theological grounding also assists Sartre in his much disputed claim to be able to found an ethics by means of his phenomenological ontology. This claim comes again in the Conclusion, immediately after the discussion of ontology and metaphysics. Sartre claims that once man has grasped that he is a 'useless passion', the possibility that freedom will 'affirm itself' opens up, meaning that the For-itself will take freedom as a value (BN 627). To do so would mean Sartre claims this explicitly in Existentialism and Humanism - affirming the freedom of others as much as that of oneself. So we arrive at a recognisably Kantian, universalistic ethics of respect for persons.

The troublesome step in this argument is of course the move from affirmation of one's own freedom, to affirmation of freedom per se. Kant gets over it (arguably) with the aid of a theory of reason which demands that I construct practical laws with a maximal degree of objectivity and impersonality with which to govern my will. Sartre does not have a theory of reason which could play this role. What he does have, though, is the idea that consciousness - freedom - is essentially a 'revelation' of being. What he may say, then, is that I stand under an obligation to value the freedom of others, because my essential being as a For-itself is essentially that of a revelation of being. ${ }^{39}$ This, however, continues to leave it unclear why the task of revealing being should necessarily assume for me a universal form. Even if what $I$ am is a task of revealing being, and even if the being that I am obliged to reveal is not just my being but being as such, still it seems strictly optional that I should interpret my obligation to reveal being in a way that will extend to you, as a distinct individual task of revelation - that $I$ should set value on your acts of being-revelation, i.e. your freedom.

What is needed is something that will shift me to an impersonal or trans-individual understanding of my task of revelation. My observation here is that, if the For-itself understands its 
own upsurge as per the onto-theological story - if it traces back its own point of origin to preindividual being - then it can no longer coherently restrict its grasp of the purposiveness of revealing being to its own individual existence, and so does have ground for conceiving its task of revealing being in universal rather than egoistic terms, i.e. for setting value on the freedom of others. ${ }^{40}$

\section{Sartre's atheism}

Let us now consider the reasons given by Sartre for thinking that a consistent existentialism, one that is genuinely humanistic, needs to be atheistic. Sartre writes:

When we think of God as the creator, we are thinking of him, most of the time, as a supernal artisan. Whatever doctrine we may be considering, whether it be a doctrine like that of Descartes, or of Leibniz himself, we always imply that the will follows, more or less, from the understanding or at least accompanies it, so that when God creates he knows precisely what he is creating. Thus, the conception of man in the mind of God is comparable to that of the paper-knife in the mind of the artisan: God makes man according to a procedure and a conception, exactly as the artisan manufactures a paper-knife, following a definition and a formula. Thus each individual man is the realisation of a certain conception which lies in the divine understanding. ${ }^{41}$

It is therefore the issue of excluding divine teleology or 'legislation' - and possibly also the theodicy or providentialism which Sartre may presume to be associated therewith - which is decisive for Sartre's atheism. And this means that there is in fact no contradiction between an onto-theology of the appropriate kind, and Sartre's 'humanistic' claim for our total and exclusive self-responsibility. A form of onto-theology like Schelling's, in which the will does not follow from 'the understanding', and in which it is held that the transition from the being of God to that of the human subject is not a relation of purposive creation through which human beings are bound to a concept of an end lying in the divine mind, supplying them with an essence which precedes their existence, does not contradict Sartre's axiom of human freedom. An onto-theology which says rather that the freedom which is God comes to be expressed in the freedom which is the human For-itself does not ascribe to us the ('paper-knife') kind of essence that Sartre objects to, since freedom conceived in Schelling's manner is nothing determinate; rather, as argued above, it provides the freedom of the For-itself with a ground. (Nor does Schelling's onto-theology introduce a relation of subordination: 
the particular sense in which according to Schelling man is necessitated by God implies that man as it were takes over from and in a sense stands equal to God.)

There is a further point to be made. Very clearly, Sartre is opposed to our representing ourselves in any sort of theistic terms: his humanist claim that the only universe is 'the human universe', that we can expect salvation from nothing but ourselves, is paramount for him. Sartre's reasons for maintaining that we must represent ourselves and our situation non-theistically have to do with our self-relation and practical orientation, with ensuring that we grasp our freedom fully, something which, he supposes, theistic self-representation makes impossible. But it would be wrong to think (as Sartre perhaps does) that this necessitates atheism. A non-theistic self-representation can be nested within an onto-theology of the right sort: so long as onto-theology does not pretend that (as Sartre put it) a 'valid proof of God's existence' can 'save man from himself', onto-theological explanation is compatible with non-theistic self-representation. Grasping our freedom fully does not, therefore, imply or presuppose an atheistic ontology. Of course, I have suggested that it is eventually important for Sartre to hold that the onto-theological story should enter into the selfunderstanding of the For-itself, namely in the context of grounding a universalist ethics, but the point is that this happens for reasons that are independent of the conditions for total selfresponsibility, which are what is at issue here.

\section{Sartre, Schelling, and Hegel}

The conclusion that I have come to may appear perilously close to the paradoxical claim that Sartre is really a non-Hegelian, onto-theologically orientated German idealist. Aside from conflicting with the entrenched image of Sartre as a rigorous atheist, my conclusion does not cohere with our impression of phenomenology and German idealism as fundamentally distinct philosophical traditions. Furthermore, it sits uncomfortably with the fact that non-Hegelian German idealism does not figure on Sartre's own philosophical landscape: there are to my knowledge no references of any significance to either Fichte or Schelling in Sartre's writings. ${ }^{42}$ Irrespective of the claim for which I have been arguing, this is puzzling, simply in view of the obvious proximity of Sartre's conception of the For-itself as a 'non-substantial absolute' to Fichte's theory of the absolute I; that Sartre should have deep affinities with Fichte and Schelling without actually having received their historical influence may not be contradictory, but it calls for comment.

I suggest the puzzling aspects of my interpretation are dissolved when the following considerations are put into focus.

In the first place we must recall Sartre's historical context. Sartre incorporated the Hegel renaissance in French philosophy in the 1930s initiated by Alexandre Kojève and Jean Hyppolite, ${ }^{43}$ 
and the great importance of Hegel for Sartre is manifest in the terminology and on almost every page of Being and Nothingness, throughout which Sartre is engaged in an extended argument with Hegel - not of course with Hegel alone, but it is Hegel rather than Husserl or Heidegger whose general metaphysical views Sartre is most keen to contest. In consequence a great deal of the attention of those commentators who take seriously Sartre's ontology has been devoted to analysing and adjudicating the argument between Sartre and Hegel. ${ }^{44}$ The appropriateness and necessity of situating Sartre in the context of Hegel cannot be doubted, if for no other reason than that many of Sartre's central claims are bound to remain hopelessly paradoxical if they are not referred for their intelligibility to Hegel's conception of dialectical form and modes of being. ${ }^{45}$ The limitations of an exclusively Hegel-centred perspective on Sartre are reflected, however, in the conclusions to which Hegel-orientated commentators on Sartre have been drawn. To give a clear instance, Klaus Hartmann, who reads Being and Nothingness 'as a union of phenomenology with Hegelian dialectic', ${ }^{46}$ concludes that, although Sartre achieves a 'consistent transformation of Hegel's Logic', ${ }^{47}$

Sartre's ontology falls short of true constitutivity, i.e., it fails to provide reasons sufficient for the comprehension of being, as divided into subject and object, and of the relation between these. What it provides is an abstract formalism, a rational model, attaching only to the existential moment of being [...] it supplies only an interpretation of being and not a foundation establishing its own cogency. ${ }^{48}$

A reading of Sartre that binds him closely to Hegel is very likely to veer towards the conclusion that Sartre is merely a lapsed Hegelian. ${ }^{49}$

In view of the radically 'defective' character of Sartre's 'Hegelianism', the suggestion which it seems natural and correct to make is that in the course of deconstructing Hegel's 'ontological optimism' Sartre reconstructs Schelling, Hegel's great antagonist: Sartre's philosophy is as it were a partial reconstruction of Schelling's, employing different materials and not brought to completion. ${ }^{50}$ The Hegelianism in Sartre is thereby accounted for, as corresponding to the elements in Schelling that either he provided Hegel with or jointly developed with Hegel.

The contention that Sartre's attempt to build a counter-ontology to Hegel's rationalism of the Concept involves an unwitting rediscovery of Schelling's alternative path of development of German idealism ${ }^{51}$ is strongly supported by Sartre's discussion of Hegel in the chapter on the origin of negation (BN 12-16), where Sartre makes exactly the key criticism of Hegel for which Schelling is well known, namely that Hegel's assumption of the symmetry of the concepts of being and nothingness, with the aid of which he is able to set his Logic in motion, is a fundamental mistake which overlooks their true extra-conceptual asymmetry. ${ }^{52}$ That Sartre should at this point and more 
generally be found thinking along the same lines as Schelling is unsurprising in view of the fact that for both thinkers the pre-rational experience of freedom is fundamental to philosophy in the sense of defining its very task.

This interpretation, as well as explaining how Sartre arrives at a position close to Schelling's, also explains why Sartre's position does not coincide with Schelling's: it is because Sartre has no developed knowledge of the possibility of a form of German idealism other than Hegel's that he supposes, implicitly, that all philosophical endeavours of an idealistic kind must be 'ontologically optimistic' and must belong, like Hegel, to the same broad metaphysical species as Descartes and Leibniz, in which the divine will follows divine understanding.

There is next the more general puzzle concerning how a phenomenologist can end up with German idealist metaphysics. The notion that phenomenology and German idealism are systematically opposed can survive, however, only if we interpret all members of the phenomenological tradition in the light of Husserl's conception of returning to the appearances and, second, interpret this methodological principle very narrowly, as if the four great phenomenologists were arguing principally about how to describe the phenomena. If this view is taken, then certainly phenomenology must be regarded as playing a different philosophical game from German idealism, since metaphysical explanation is excluded $a b$ initio from its aims. But there is a readily available way of bringing both philosophical movements under a single heading which directs us to what they have in common: both are species of transcendental philosophy. The concept of the transcendental has many meanings, but it is hardly contentious to suggest that the phenomenologists may be read as circling around a complex of issues formulated by Kant - concerning the subject-object relation, the nature of transcendental explanation and subjectivity, the grounds for rejecting naturalism, and so on. These Kantian ideas are to some degree built in to what the phenomenologists understand by returning to the appearances; Kantianism is reflected in their anti-empiricist conception of what this amounts to. Since the German idealists were also and more overtly grappling with Kant's legacy, it should come as no surprise that their circlings around Kant, and those of the phenomenologists, should intersect at many points, and even that the phenomenologists should end up, on occasion, either recapitulating German idealist ideas or, as I have tried to show with respect to Sartre, bordering on and standing in need of them.

Finally, there is a straightforward explanation to be given for why Sartre's philosophy should be continuous with theology. It is not misleading to describe Sartre's humanism as a quasideification of man that follows a well established Left Hegelian pattern: like Feuerbach, Sartre transfers back to Man the predicates that Man has in religion mis-ascribed to God. The predicates of freedom and absoluteness are transferred directly while others are inverted in the course of being transferred - the highest being becomes le néant, and so on. The intensity of Sartre's sense of the 
metaphysical significance of human existence - the feature which made Sartre's philosophy anathematic to later French philosophy - has ultimately a theological origin. What I have tried to suggest is that Sartre's philosophy can be returned to this logical and historical origin without its spirit being betrayed. ${ }^{53}$ 


\section{Notes}

${ }^{1}$ This is not true of German commentary: see Manfred Frank, Zeitbewußtsein (Pfullingen: Neske, 1990), Der unendliche Mangel an Sein. Schellings Hegelkritik und die Anfänge der Marxschen Dialektik, 2nd edn (Munich: Fink, 1992) (extracts from which are translated as 'Schelling and Sartre on being and nothingness', trans. Judith Norman, in The New Schelling, (ed.) Judith Norman and Alistair Welchman, London: Continuum, 2004); Klaus Hartmann, Sartre's Ontology: A Study of Being and Nothingness in the Light of Hegel's Logic (Evanston: Northwestern University Press, 1966); Joseph Möller, Absurdes Sein? Eine Auseinandersetzung mit der Ontologie J. P. Sartres (Stuttgart: Kohlhammer, 1959); Gerhard Seel, Sartres Dialektik. Zur Methode und Begründung seiner Philosophie unter Besonderer Berücksichtigung der Subjekts-, Zeit- und Werttheorie (Bonn: Bouvier, 1971), republished in an expanded and revised edition as La dialectique de Sartre, trans. E. Müller, Ph. Muller and M. Reinhardt (Lausanne: L'Age de l'Homme, 1995); and Michael Theunissen, The Other: Studies in the Social Ontology of Husserl, Heidegger, Sartre, and Buber, trans. Christopher Macann (Cambridge, Mass.: MIT Press, 1986), and 'Sartres negationstheoretische Ontologie der Zeit und Phänomenologie der Zeitdimensionen', in Negative Theologie der Zeit (Frankfurt am Main: Suhrkamp, 1997). The main anglophone exception is Joseph S. Catalano, A Commentary on Jean-Paul Sartre's 'Being and Nothingness' (Chicago: University of Chicago Press, 1974).

2 Thomas Baldwin, 'Two approaches to Sartre', European Journal of Philosophy 4, 1996, p. 85; see also pp. 88-89.

${ }^{3}$ Gregory McCulloch, Using Sartre: An Analytical Introduction to Early Sartrean Themes (London: Routledge, 1994), pp. 3-4.

${ }^{4}$ Phyllis Sutton Morris, Sartre's Concept of the Person: An Analytic Approach (Amherst: University of Massachusetts Press, 1975).

${ }^{5}$ Existentialism and Humanism (1946), trans. Philip Mairet (London: Methuen, 1973), pp. 27-28. There are dangers in treating Existentialism and Humanism as a kind of belated appendix to Being and Nothingness, but an assumption of substantial continuity appears justified in light of the fact that Sartre presents himself in Existentialism and Humanism as defending the philosophical outlook articulated in the earlier work.

6 'Materialism and revolution' (1946), in Literary and Philosophical Essays, trans. Annette Michelson, London: Hutchinson, 1955), p. 187.

${ }^{7}$ As Seel puts, the Husserlian-Heideggerean interpretation of Sartre is 'dangereusement unilatérale' (La dialectique de Sartre, pp. 13-14).

${ }^{8}$ Maurice Merleau-Ponty, Phenomenology of Perception (1945), trans. Colin Smith (Routledge, 1994), pt. III, ch. 3. Merleau-Ponty should not be regarded, however, as under-estimating the significance of ontology for Sartre (or in philosophy in general). Though in the chapter cited Merleau-Ponty does appeal to the phenomena of common experience as evidence against Sartre, the Phenomenology as a whole provides this discussion with deep ontological underpinnings, in the form of a critique of the ontology of 'objective thought' from which Merleau-Ponty considers Sartre to have failed to escape entirely.

${ }^{9}$ The present paper develops some of the claims sketched in section III of my 'Sartre, intersubjectivity, and German idealism', Journal of the History of Philosophy 43, 2005, pp. 325351.

${ }^{10}$ I am concerned in this paper only with the 'early', pre-Marxist Sartre. Quotations from Being and Nothingness, prefixed by 'BN', are taken from Jean-Paul Sartre, Being and Nothingness: An Essay in Phenomenological Ontology (1943), trans. Hazel E. Barnes (London: Methuen, 1958).

${ }^{11}$ Though Sartre does occasionally refer to the limitations of language in explaining his formulae, e.g. BN xli, '[...] our first formula can be only an approximation due to the requirements of language'. 
${ }^{12}$ Ages of the World, 2nd draft, 1813, trans. Judith Norman (Ann Arbor: Michigan University Press, 2001), pp. 123-124.

${ }^{13}$ Ages of the World, p. 136; italics added.

${ }^{14}$ A point of terminology: In characterising Schelling's position as onto-theological, I follow standard usage in commentary on post-Kantian authors, and understand by onto-theology a philosophical position that regards the intelligibility of our and the world's being as bound up metaphysically with the concept of a highest being (God) conceived as having at least some attributes of personality, mind, or subjectivity, in some sense and to some degree. Onto-theology therefore does not coincide with (classical) theism.

15 This conclusion bears comparison with that of Möller, in Absurdes Sein?, pt. III: the limitations of Sartre's metaphysics, Möller claims, show the necessity of attributing absoluteness not to consciousness but to being. Möller allows himself, however, at several points in his critique of Sartre, assumptions that appear to beg the question against Sartre.

${ }^{16}$ Illuminating studies of the Fichte-Sartre relation may be found in Daniel Brezeale, 'Vom Idealismus zum Existenzialismus Direttissima: Fichte/Sartre', and Dorothea Wildenburg, 'Ist der Existentialismus ein kritischer Idealismus? Fichte und Sartre - Versuch einer Annäherung', both in Fichte-Studien 22, 2003 [Helmut Girndt (ed.), Fichte in Geschichte und Gegenwart], pp. 171-192 and pp. 198-208 respectively. Wildenburg, Ist der Existentialismus ein Idealismus? Transzendentalphilosophische Analyse der Selbstbewußtseinstheorie des frühen Sartres aus der Perspektive der Wissenschaftstheorie Fichtes, Fichte-Studien-Supplementa vol. 17 (Amsterdam/New York: Rodopi, 2003), provides a detailed account; see also Wildenburg, 'Entgegensetzung als konstitutives Element des Selbstbewusstseins: Fichte und Sartre in der Nachfolge Kants', in Volker Gerhardt, Rolf-Peter Horstmann and Ralph Schumacher (eds.), Kant und die Berliner Aufklärung. Akten des IX Internationalen Kant-Kongresses (Berlin: de Gruyter, 2001), vol. 5, pp. 619-629. Both Brezeale and Wildenburg, while acknowledging some important differences, affirm the extremely close parallelism of Sartre and Fichte. Their view seems to me substantially correct. One important limitation of a Fichtean reading of Sartre shows up with regard to Wildenburg's suggestion that Sartre's In-itself be understood as having the same immanent status as Fichte's Ansto $\beta$. This is indeed required for a thoroughgoing Fichteanisation of Sartre, but its relocation of the In-itself within the bounds of intelligibility appears directly contrary to Sartre's intentions. On my account, the In-itself is closer to Schelling's unvordenkliche Seyn (a point raised in the final section of this paper), and Sartre's philosophy needs to be read as a combination of Fichtean and Schellingian elements.

${ }^{17}$ Philosophie und Religion, in Friedrich Wilhelm Joseph von Schellings sämmtliche Werke, 14 vols., (ed.) Karl Friedrich August Schelling (Stuttgart: Cotta, 1856-61), I/6, pp. 38-40.

${ }^{18}$ Since 'temporality comes into being through the for-itself', 'historical becoming' is not at issue in metaphysics (BN 621).

${ }^{19}$ Sartre describes ontology as 'furnish[ing] information which serve as the basis for metaphysics' (BN 620). Seel suggests with some plausibility that ontology is an enquiry that proceeds from the cogito, while metaphysics proceeds from being (La dialectique de Sartre, p. 264).

20 'I am both one of the terms of the relation and the relation itself' (BN 624).

${ }^{21}$ A tension which is, indeed, visible in the opening quotation from Existentialism and Humanism, when, having made a non-Copernican claim for the non-existence of God, Sartre adds the Copernican rider, '[...] even if God existed that would make no difference from its [existentialism's human] point of view'. Note that the question whether Sartre's outlook is Copernican in the sense employed here goes beyond the question whether Sartre is some sort of transcendental idealist (as Baldwin plausibly claims, 'Two approaches to Sartre', p. 86), since transcendental idealism may be given either a Copernican or a non-Copernican reading.

22 Theunissen notes something similar: he says that though Sartre 'subjectivises' time, there is a counter-movement to this in Sartre's idea that the For-itself gets temporalised, i.e. becomes 
temporal in consequence of some trans-subjective ground ('Sartres negationstheoretische Ontologie der Zeit', p. 131).

${ }^{23}$ Sartre perhaps confuses something's being a question about the For-itself, with its being a question internal to the perspective of the For-itself.

${ }^{24}$ This point derives from Uwe Töllner, Sartres Ontologie und die Frage einer Ethik. Zur Vereinbarkeit einer normativen Ethik und/oder Metaethik mit der Ontologie von L'Être et le néant (Doktorarbeit/Dissertation, Universität Hamburg, 1995), ch. 5, where it is argued that the untenability of Sartre's account of the genesis of the For-itself undermines his thesis that the Foritself lacks, as opposed to merely does not possess, the mode of being of the In-itself.

${ }^{25}$ Criticisms of Sartre's handling of the questions of the upsurge of the For-itself and/or of the totality of being may be found in Vincent Descombes, Modern French Philosophy (Cambridge: Cambridge University Press, 1979), p. 53, Hartmann, Sartre's Ontology, pp. 143-145, F. Rouger, Le Monde et le Moi. Ontologie et système chez le Premier Sartre (Paris: Méridens Klincksiek, 1986), pp. 259-264.

${ }^{26}$ See BN 622: 'we must take into account what is required of an existent if it is to be considered a totality $[\ldots]^{\prime}$

${ }^{27}$ Consciousness 'is bound to the in-itself by an internal relation' (BN 621).

${ }^{28}$ Compare Kant's treatment of the mathematical antinomies, where it is shown that the standpoint from which we are obliged to raise questions about 'the world as a totality' can be avoided through turning to transcendental idealism. That Sartre does not adopt a parallel solution here is again a sign of his non-Copernicanism or imperfect Copernicanism.

${ }^{29}$ Sartre could not take up Vaihinger's position without reducing the concepts of freedom and Foritself to fictions, and such a position, even allowing that Vaihinger's sense of 'fiction' is not the ordinary one, is clearly alien to Sartre: while Sartre is anti-realist about many things, he is (as we, though not Sartre himself, would put it) an all-out realist about freedom; a fictionalist understanding of Sartre's account of the For-itself would amount to giving Sartre's ontology the philosophically inferior, questionable status that Sartre reserves for what he calls 'metaphysics'. There is a further, equally conclusive reason why Sartre's 'as if' cannot be Vaihinger's. In his chapter on 'practical fictions', Vaihinger describes freedom or absolute responsibility as 'a logical monstrosity', 'a contradiction', an 'impossibility', and yet as, 'in spite of its unreality', 'quite justifiable', 'one of the most important fictions ever formed by man' (Hans Vaihinger, The Philosophy of 'As If', trans. C. K. Ogden (London: Routledge \& Kegan Paul, 1949), pp. 43-44). Vaihinger's 'justification' of freedom derives from the scientific positivism with which his fictionalism is correlated (see pp. xli-xlii, xliiixliv, and 1-8): life leads us to fictions such as freedom which are grounded ultimately in our biological constitution. Sartre is of course utterly opposed to such naturalism.

${ }^{30}$ The pattern observed in the last two sections repeats itself in other areas of Sartre's philosophy. Sartre's solution to the epistemological problem of the Other leads, I have argued elsewhere ('Sartre, intersubjectivity, and German idealism', sections I-II), to a conception of intersubjective metaphysical structure which is essentially the same as that which we find in Fichte and Schelling: Sartre's theory of intersubjectivity encounters, I argue, a problem which can be solved only by regarding the intersubjective awareness of each For-itself as mutually implying and presupposing moments of a single, trans-individual structure. There is thus a parallel between Sartre's theory of intersubjective awareness and the problem surrounding Sartre's invocation of the concept of 'detotalised totality' in his account of being as a whole. As noted earlier, Sartre also invokes this notion to describe the unity formed by self and other: together you and I comprise a 'detotalised totality'. The parallel is that, just as the notion of detotalised totality fails to stand up as a final term of philosophical explanation in general ontology, so too in the context of intersubjectivity it proves impossible for Sartre to get away with less than full, un-detotalised totality; intersubjectivity is another instance where Sartre's story needs to be supplemented with German idealist metaphysics. The metaphysical structure which Sartre requires to ground episodes of inter-subjective awareness need not, I argue, incorporate any of the specifically Hegelian theses that Sartre finds objectionable: 
the fact that Sartre unequivocally rejects Hegel's idea of an 'I that is a We' gives him no reason to reject the less loaded, less collectivist structure posited by Fichte and Schelling.

${ }^{31}$ Though it does not correspond to what Sartre claims in Being and Nothingness, there is at least a hint of this approach in the Critique of Dialectical Reason's neo-marxist vision of collective human history. See Theunissen, The Other, pp. 243-254.

${ }^{32}$ J. G. Fichte, The Science of Knowledge (1794), (ed. and trans.) Peter Heath and John Lachs (Cambridge: Cambridge University Press, 1982).

${ }^{33}$ For example, suggestive of Fichtean metaphysical practicalism is Sartre's distinctive and frequent use of the formula 'avoir à (ne pas) être': he says the For-itself's manner of not being the world, matter, etc. 'is to have to not-be this table, this glass', etc. (BN 183). But there is much else to be said: see note 000 above.

${ }^{34}$ Wildenburg, Ist der Existentialismus ein Idealismus?, ch. 6, compares Sartre and Fichte with respect to the primacy of the practical.

35 'The very use of the term "freedom" is dangerous if it is to imply that the word refers to a concept as words ordinarily do' (BN 438).

${ }^{36}$ When Sartre calls the For-itself a 'nothingness' he does not mean that it is an illusion: that is not what he wants to claim but what he wants to rule out. The possibility that Sartre needs to rule out is not that the For-itself is nothing in the sense of néant - that is what Sartre himself says that it is but that it is nothing in the sense of rien.

${ }^{37}$ Sartre himself articulates the possibility that reality be attributed only to the 'pure in-itself' (BN 622), but this is in connection with the problem discussed above of determining being as a totality, and not envisaged as motivated in the skeptical way suggested here.

${ }^{38}$ Sartre does not countenance the idea of a ground of freedom presumably because he cannot envisage a ground that does not import (to him) objectionable rationalist-idealist Hegelian features. There is no space to explore the theme here, but it may be noted that Schelling also gives, in the Weltalter, an account of time that offers itself as a way of grounding Sartre's conception of the Foritself's temporality; see Frank, Zeitbewußtsein. Talk of grounding the freedom and structures of the For-itself requires care. It is of course crucial for Sartre that freedom not have grounds of a certain sort, viz. ones that would give it a determinate content, that would be in any way causal, or that would in any other sense pretend to 'explain' freedom. Yet Sartre can allow a grounding in the thinner, transcendental sense of a philosophical demonstration of the possibility of our freedom: if it were Sartre's view that freedom must be without grounds in any and every sense, then he would betray this view merely in raising the question (in granting legitimacy to the concept) of the origin of the For-itself. In considering whether Sartre can allow that freedom has a ground (of Schelling's sort) it is important not to be misled by an ambiguity concerning whose freedom is in question. For Schelling, just as much as for Sartre, freedom per se is groundless in the sense that there is no reason for its being; Schelling grounds freedom only in the sense that he traces back our freedom, the freedom of human beings, to pre-human, divine freedom. This conception of human freedom as having a ground in the sense that freedom is transmitted to human being from an ontologically prior source, while remaining groundless in the sense that freedom per se has no reason for its being, does not contradict Sartre's 'abyssal' conception of freedom.

${ }^{39}$ And this is what he does say, in posthumously published texts written after BN; see 'Sartre, intersubjectivity, and German idealism', section IV.

${ }^{40}$ My suggestion is not, note, that the Kantian strategy of deriving theology from the moral law may be imputed to Sartre. It is only that the onto-theological story throws a bridge across the gap separating Sartre's theoretical philosophy from his (imperfectly grounded) ethics, and that this gives Sartre, from the point of view of the completeness of his system as a whole and of grounding his ethics, an additional reason to accept the onto-theological story, assuming that it can be established on independently, as I have argued it can. There is no scope in Sartre for an inference back from ethics to onto-theology, since Sartre is not in a position to treat the moral law as an epistemologically authoritative Kantian 'fact of reason' or as anything analogous thereto. 
${ }^{41}$ Existentialism and Humanism, p. 27.

${ }^{42}$ Ronald Hayman lists Fichte among the numerous writers whose works Sartre read in his third year at the École Normale Supérieur (Writing Against: A Biography of Sartre (London: Weidenfeld and Nicolson, 1986, p. 55). I have not been able to determine the scope of the syllabus at the École, but Sartre implies that Hegel was not included within the syllabus at the École (Search for a Method, trans. Hazel Barnes, New York: Vintage, 1968, p. 17: 'The horror of dialectic was such that Hegel himself was unknown to us') and if the prevailing French neo-Kantianism of the time denied value to Hegel, so it would have done also, presumably, to Fichte and Schelling. In an interview (published in Paul Arthur Schilpp (ed.), The Philosophy of Jean-Paul Sartre, LaSalle, Ill.: Open Court, 1981) Sartre says that he 'had the idea of ontology in mind because of my philosophical training, the courses I had taken. Philosophy is an enquiry concerning being and beings. Any thought that does not lead to an enquiry concerning being is not valid' (p. 14). He refers on the same page to Schelling but only as an example of a philosopher to whose work the 'early/late' distinction applies. In the Cahiers pour une morale (1947-48) (Paris: Gallimard, 1983) there is a quotation from Kojève which refers to Fichte and (early) Schelling alongside Hegel (p. 49), and a reference to Hegel and Fichte as holding to the assimilability of the Not-I to the I, a view which Sartre rejects (p. 514). As far as I have been able to determine, the likeliest path of transmission of loosely Schellingian ideas to Sartre is via the (Kierkegaardian) existentialism of Jean Wahl: see Search for a Method, p. 19, and Bruce Baugh, French Hegel: From Surrealism to Postmodernism (London: Routledge, 2003), pp. 35 and 95.

${ }^{43}$ See Hartmann, Sartre's Ontology, Introduction, Michael Kelly, Hegel in France (Birmingham: University of Birmingham), chs. 5-6, and Descombes, Modern French Philosophy, ch. 1. A slightly different impression emerges from Baugh, French Hegel, ch. 1.

${ }^{44}$ Hartmann's and Seel's books, which must be counted among the best studies of Sartre's philosophy, are constructed on a Sartre-Hegel axis.

${ }^{45}$ See Hartmann, Sartre's Ontology, pp. 127-128. This of course helps to account for the disinclination of analytic commentators to engage with the ontological theory in Being and Nothingness.

${ }^{46}$ Hartmann, Sartre's Ontology, p. 139.

${ }^{47}$ Hartmann, Sartre's Ontology, p. 132.

${ }^{48}$ Hartmann, Sartre's Ontology, p. 147; Hartmann's criticisms are on pp. 135-148. As if recognising the limitations of the Hegelian mould for the interpretation of Sartre, Hartmann makes a highly original comparison of Sartre with Hegel's romantic contemporary, Karl Solger (Sartre's Ontology, Appendix). Solger's metaphysics is however relatively sketchy and indistinct, and appears directly open to Hegelian criticism, such that Hartmann is able to conclude that Sartre's and Solger's limitations mirror one another.

${ }^{49}$ Seel, while recognising that Sartre rejects Hegel's panlogicism, attempts to reconstruct Sartre as a dialectical philosopher and to do so in a way that responds to Hartmann's criticisms (La dialectique de Sartre, pp. 52-53 and $97 \mathrm{ff}$.). It is to be observed however that in his attempt to make Sartre consistent, Seel ascribes to Sartre (pp. 300 ff.) the orthodox Kantian position on the transcendental ideas of reason, while acknowledging that for Sartre, unlike Kant, the concept of God is contradictory (p. 305). Whether or not this Kant-Hegel combination is coherent, it certainly seems to leave room for the alternative post-Kantian alignment that I have suggested of Sartre with Schelling.

${ }^{50}$ Manfred Frank is the only commentator known to me who has explored the relation between Sartre and Schelling: see the works of his cited in note 1.

${ }^{51}$ This appealing view of German idealism as having not a unilinear but a 'two-path' structure is the overall thesis of Miklos Vetö: see De Kant à Schelling. Les deux voies de l'Idéalisme allemand (Grenoble: Millon, 1998).

${ }^{52}$ Sartre criticises Hegel for reducing being to one more 'moment of the object' (BN 13) and for treating being and nothingness as 'logically contemporary' (BN 14). 
${ }^{53}$ I am grateful to the audience at the Department of Theology and Religious Studies at King's College London for helpful comments on an earlier draft of this paper, to two referees for Religious Studies whose helpful reports prompted several important clarifications, and to Christopher Hamilton and Sarah Richmond for help in writing the final version of the paper. 